During the week, tours were arranged to the museums of Birmingham and Warwick, an archæological site at Weoley Castle, Althorp, the seat of Earl Spencer, and a tour of the canals to Wolverhampton. At the meeting, Dr. F. S. Wallis (Bristol) was elected president for 1955-56, and it was decided to hold the next conference in Amsterdam, probably at the end of June 1956.

\section{THE NATIONAL OCEANOGRAPHIC COUNCIL}

\section{ANNUAL REPORT FOR 1953-54}

$\mathrm{T}$ HE National Institute of Oceanography is now firmly established at its new premises at Wormley, near Godaiming, Surrey, and the Discovery Committee collections and staff are comfortably housed there, apart from a small group still accommodated at the British Museum (Natural History).

In the Institute's report on research during the year April 1, 1953-March 31, 1954*, two topics of particular interest on the physical side are the relationship between waves, wind and swell, and the transfer of energy between air and sea; these studies have involved not only the co-operation of the Liverpool Tidal Institute but also that of the Department of Meteorology of the Imperial College of Science and Technology, London. An expedition, made possible by a grant from the Royal Society, was run jointly with the latter to investigate energy exchange between air and sea at the flat Island of Anegada in the West Indies. Much important data were gathered and will be reported in detail by Prof. P. A. Sheppard, Mr. H. Charnock and others. Several pieces of new apparatus have been developed or improved. These include improvements to the electro-mechanical filter of the wave analyser, further developments to the electromagnetic flowmeter and a new type of recording camera which takes $175 \mathrm{ft}$. of photographic paper. In collaboration with Kelvin Hughes, Ltd., Dr. J. N. Carruthers has developed a 'streamed cone' current meter allowing for instantaneous measurements of current speed and direction.

On the biological side, advances have been made in the study of krill (Euphausia superba), which is the main food of the larger animals in the Antaretic. Mr. J. W. S. Marr has been able to establish that this organism is confined to Antarctic waters and lies mainly in the drift from the Weddell Sea and in the East Wind Drift close to the continent. A comparable study of the chætognath, Sagitta gazellae, has nearly been completed by Mr. P. M. David. Mr. A. de C. Baker has shown that common species of phyto- and zoo-plankton have a circumpolar range and leaves little doubt that populations are continuous around the antarctic circle. Further work is being carried out on the material brought back from the expedition on the Royal Research Ship William Scoresby to investigate the Benguela Current.

There is still much study to be done on the large collections built up under the Discovery Committee, and a number of specialists are engaged on this. The most recent work to be published on these collections was Captain A. C. Totton's monograph on the Siphonophora of the Indian Ocean. Considerable work has been carried out through international

* Annual Report of the National Oceanographic Council, 1 April 1953-31 March 1954. Pp. $\mathbf{v}+28$. (Cambridge: At the University Press, 1955.) 5s. net. collaboration on whale-marking, thanks largely to a number of whaling companies for lending a modern diesel-driven whale-catcher, the Enern. In addition, a number of papers by members of the staff have been published which are important to the study of the life-history and migration of whales.

The Royal Research Ship Discovery II has been refitted with a number of new items, including an up-to-date radar set and position-finding equipment. The 1954-55 programme includes a study of deepwater movements in respect of density distribution and other factors. The biological work includes new methods of sampling and observing deep-sea organisms. Investigations will also be earriod out using the carbon-isotope method for studying photosynthet;c activity. In addition, the ship will also provide facilities for the Admiralty, Sir Edward Bullard and the University of the West Indies for various research purposes. After twenty-eight years of service, the William Scoresby has sadly been put in the hands of the shipbreakers. She operated largely as a whale-marker, but during the Second World War served as a minesweeper and patrol vessel in the Falkland Islands area; in 1949 she returned to her work of whale-marking, but only managed one cruise in this capacity under the National Oceanographic Council.

This account of the work of the Council is only a brief summary, and of necessity much of interest has had to be omitted; but much credit is due to the Couneil and to the energies of Dr. G. E. R. Deacon, director of the National Institute of Oceanography, and his staff for the rapid development of research after the major upheaval of changing premises and equipping new laboratories.

C. D. Ovey

\section{THE GOLDEN EAGLE IN AMERICA}

7 HE golden eagle (Aquila chrysaetos canadensis) 1 is widely distributed in mountains and adjacent plains throughout much of the northern hemisphere. Its principal breeding-range in North America extends from the Arctic Ocean south into Mexico, westward from the 99 th meridian. As it nests from near sea-level to the timber-line, it may be found in a wide variety of habitats and in winter it occurs practically throughout this country. Its food habits are as varied as the diversified habitats in which it lives. These, and the economic status of the eagle, have been described by Lee W. Arnold in a publication of the Fish and Wildlife Service of the United States Department of the Interior (Circular 27).

The golden eagle has been known to kill and eat more than sixty different kinds of animals, ranging from full-grown deer and antelope to mice, birds, frogs and insects. Both living creatures and dead are included in its diet, and at times it accepts carrion even though living prey is available.

Rabbits and rodents form the staple diet of the golden eagle, the proportion taken varying with local conditions. During the nesting season on a Colorado antelope range, rabbits supplied most of the golden eagle's food; under winter conditions on a North Dakota pheasant refuge, they comprised approximately 19 per cent.

On occasion, the bird will kill adult and young antelope, although in northern Colorado, where four pairs of eagles nested in close proximity to antelope at fawning time, such predation was negligible. 
Although the golden eagle will kill either the adult or the young of deer, no evidence was found to indicate that the bird is more than a minor influence when compared to other factors controlling deer populations.

Depending on local conditions, the golden eagle exerts a varying pressure on upland game birds, and at times this pressure may be sufficient to warrant eagle control. The harassing of upland game, thus keeping them from feeding properly in severe weather, may be more serious than the actual killing activities of the eagle. When nesting in the vicinity of waterfowl areas, the golden eagle may feed its young largely on these birds.

Golden eagles at times kill domestic lambs. The extent of this damage varies with local conditions. On occasion, they kill calves or may even contribute to the death of full-grown cattle. All evidence indicates that this is an exceptional activity.

Golden eagles occur in varying numbers on more than sixty-five Federal wild-life refuges where, in general, they serve a beneficial purpose in consuming wounded, sick or dead ducks and forage-consuming jack-rabbits and rodents.

\section{RESEARCH ON FOREST PRODUCTS}

$\mathrm{T}$ HE strength properties of plywood have already been considered in Bulletin No. 29 of the Forest Products Research Laboratory, Princes Risborough, entitled "Comparison of 3-Plywoods of a Standard Thickness, Part 1" (see Nature, 174, 383 ; 1954). In Bulletin No. 33 on "The Strength Properties of Plywood, Part 2: Effect of the Geometry of Construction"*, the author states that an increasing demand for data on the mechanical properties of plywoods exists; but owing to the wide variety of constructions and thicknesses now available, it is not possible to obtain these data by testing procedures alone. To cover the whole field, some simple methods for estimating strength from limited basic data are required, and this the author sets out to do. This investigation has become necessary because plywoods have become a structural material and can now be produced in forms practically indestructible by delamination. It is stated that increasing quantities are being used, for box and web types of girder, panel floors and walls, ship's planking and concrete shuttering. The trouble is the large variety of thicknesses and different forms of construction, all of which cannot be tested. The coming of plywood in this extensive form of utilization will be very beneficial to the tropical and subtropical forester in charge of forests containing large mixtures of species of trees of which until comparatively recently only a few luxury timbers were marketable. A number of others are now being used, and sylviculturally the management of the forests should become more intensive with the improvement of working plans.

The Bulletin contains the results of an investigation. to provide suitable equations for calculating the bending, tension, compression and shear strengths of any plywood construction. All the tests are carried out on African gaboon. From the results, equations

* Forest Products Research. Bulletin No. 33: The Strength PropPp. iv $+28+4$ plates. By W. T. Curry. (London: H.M.S.O., 1954.) 2s. net. have been formulated which can be used in practice for calculations or constructions of any other species of wood. An appendix to the Bulletin shows how they can be applied.

Bulletin No. 32 of the Forest Products Laboratory entitled "Field Tesís on Wood Preservatives used for Pressure Treatment"* describes experimental work carried out during 1929-53. The lengthening of the life of wood for the various purposes for which it has for so long been used by man has always been a factor for some consideration, especially in tropical countries where perhaps the matter has been more in the forefront of both forester and wood user. So long ago as the 1860 's, when railway construction was being carried out on an intensive scale in northern India, the supplies of the valuable Himalayan deodar threatened to give out, and sleepers were.cut from the Pinus longifolia which was abundant in the lower hills. Creosote was brought out from Britain and applied cold without any protective effect. It was more than half a century before the railway authorities tried this timber again for the purpose.

In temperate climates, in Europe at least, some form of preservative for wood structures has for long been under experiment. So far the hightemperature creosotes have proved to be the most effective preservative under test. The method employed is to set out a small 'graveyard' of small blocks of a perishable wood (the agar wood is chiefly used) and these are treated with graded concentrations of the preservative under test, untreated wood blocks being side by side with the treated ones. The treated blocks are kept for a few months with a specific fungus growing on a nutrient agar medium. Periodical examination of the blocks is undertaken, one of the tests being done at Princes Risborough, a second at Thetford and the third at Dolgelly. None is as yet complete.

The results already obtained, however, do give some indication of how effective most of the treatments are likely to be. So far, the high-temperature creosotes have proved to be the best preservative under test; all are highly effective, and after twenty years there is no sign of any difference between them. The lowtemperature creosotes, however, do not appear to be quite so effective. At present there is not much to choose between the various modern water-soluble preservatives under test, although 'Ascu' appears to be the most promising. $\quad$ E. P. STEBbing

* Forest Products Research. Bulletin No. 32: Field Tests on Pp. iv $+52+1$ plate. (London : H.M.S.0., 1954.) 2s. 6d. net.

\section{SPITSBERGEN TERTIARY COAL FOSSILS}

CVEIN MANUM has reported on the pollen-grains $S$ and spores to be observed in coal deposits of Tertiary age in west Spitsbergen (Norsk Polarinstitutt, Med. 79, pp. 1-9 ; 1954 ; English summary).

The Tertiary formation, of Palæocene-Eocene age, comprises several coal seams of which a preliminary analysis of the contents of pollen and spores has now been made. The numbers of microfossils, as well as their state of preservation, are highly variable. All grains and spores are completely flattened in the coal and do not regain their round shape after maceration. The pollen and spores thus far observed have 